\title{
Political Connection and Real Earnings Management in Nigeria
}

\author{
${ }^{1}$ Ahmad Haruna Abubakar, ${ }^{2}$ Peter U Anuforo, ${ }^{3}$ Dahiru Hussaini, ${ }^{4}$ Musa Isa \\ ${ }^{1}$ Faculty of Business and Management \\ ${ }^{2}$ Universiti Sultan Zainal Abidin, Malaysia \\ ${ }^{3}$ University of Maiduguri, Nigeria \\ ${ }^{4}$ Department of Accounting Jigawa State Polytechnic Dutse
}

ahmadhabubakar@gmail.com

\begin{tabular}{ll}
\hline \multicolumn{2}{l}{ ARTICLE DETAILS } \\
\hline History & \\
Received & February \\
Revised Format & : March \\
Accepted $\quad$ :April \\
\hline
\end{tabular}

Keywords :

political connection, earnings management, earnings quality, Nigeria.

\begin{abstract}
S
There is currently exists an important question on whether firm's political network affect the level of their earning information. The aim of this study is to examine the influence of political connection on real earnings management. The analyses involve a sample of 72 non-financial firms with 360 firm-year observations for a five-year period (2014-2019). Data was obtained from the annual reports of these companies as well as from Thompson Reuters and Bloomberg databases. The Panel Corrected Standard Error was used to test the model studied. The finding shows that firms board with political connection are possible to have earnings manipulation which deteriorate the earnings quality. Thus, this study recommends that increased attention should be given to internal control mechanisms to help curtail corporate earnings manipulations, reduce the effect of political connection, and enhance the financial reporting quality,
\end{abstract}

\section{INTRODUCTION}

The financial statements are a major means through which companies communicate to their users their financial results as well as position. All stakeholders particularly investors and regulators rely on the audited earnings numbers and disclosures as the bases for making their business and investment decisions (Abubakar, Lawal, \& Mohamed, 2020). Thus, the financial report should not be prepared to deliberately misinform users. Instead, the statement must deliver reliable, relevant, and timely information to assist users' decision making (Rahman \& Mansor, 2018; Bala, Amran, \& Shaari, 2019). Unfortunately, managers normally use the financial statement to deceive the investors by hiding the true value of the firm using earnings management (Lo, Ramos \& Rogo).

The practice of EM had led to several accounting scandals and failures globally (e.g., Enron, Worldcom, and Xerox), and in Nigeria the case of Oando oil Plc and Arik airline are the recent corporate frauds recorded in 2017. This made investors raised serious concern on the credibility and reliability of the financial reports (Nwanyanwu, 2017). Thus, EM is the act of intentionally manipulating the reported financial statement numbers by managers to mislead information users in order to achieve the managers' own gains or pre-set objectives (Healy \& Wahlen (1999).

There is currently exists an important question on whether firm's political network affect the level of their earning information. Firms with political connection are more readily 
available to other sources of capital and other benefits through their network (Ghonji Feshki, Khanmohammadi, \& Yazdani, 2020). There are two contending views on the director's political connections. The first proponent argue that political connection has the incentive to manipulate the reported earnings which can result to a low earnings quality (Jaffar \& Abdul- Shukor, 2016). While some studies argue that politically connected firms are believed to enjoy economic and derive financial benefit as a result of their network connection with the government (Chaney, Faccio, \& Parsley, 2011).

According to Cao, Lemmon, Pan, and Tian (2009) politically connected firms have preferential treatment on lighter taxation, easy access to bank loans, raw material, and relaxed regulations. It was established in Nigeria that $54 \%$ of the firm have political connection (Osazuwa, Che-Ahmad, \& Adam, 2016). According to the political connection theory, firm's political connection may influence the level of firm performance (Zhang, 2014). It was reported by Abdul Wahab and Holland (2012) that politically connected directors can lead to low earnings quality, and higher agency problem.

From the above-mentioned facts, this study aims to examine the effects of firm's political connection on earnings management. Thus, the findings inform policymakers, shareholders, and regulators on the importance of effective corporate governance rules would reduce the effect of political connection thereby increasing the transparency and the quality of the financial statement.

The rest of this paper is prepared as follows. Section 2 reviews the relevant studies and discusses the proposed hypotheses. Section 3 provides details of the data and methodology while section 4 presents and discusses the results. Finally, section 5 presents the conclusions.

\section{Literature Review and Hypothesis Development}

According to grabbing hand theory firms use their political connection to divert the resources of the firm (Wong, \& Hooy, 2018). While the helping hand theory view political connection as an opportunity for firm to have access to subsidies and contract which would improve the performance of the firms (Ngan, 2013). Extent studies documented the association between political connection and earnings management. Among others Braam et al. (2015) found that there is a link between political connection and aggressive earnings management. Also, managers have the possibility of switching from accrual to real earnings management. In Iran, Ghonji Feshki, Khanmohammadi, and Yazdani (2020) examines weather political connection serve as means by firm listed on Tehran Stock Exchange to manage earnings. The authors found a positive significant association between political connection and Real earnings management. Firms' political connection provides a motivation for the firms to engage into earnings manipulation (Zhang, 2014)

On the other hand, Junaidi and Siregar (2020).in line with the helping hand theory found there is no relationship between political connection and earnings management practice among non-financial listed companies in Indonesian stock exchange. Also, Ma, Ma, and Tian (2013), Wang (2015), and Song, Wang and Yan (2011) documented that firm having political connection disclosed a higher earnings quality than the non-connected firms. In view of the foregoing, the following hypothesis is developed:

H1: There is a significant relationship between political connection and real earnings management. 


\section{RESEARCH METHODOLOGY}

The study population contains of 169 firms listed on the Nigeria Stock Exchange from 2014-2019. Table 1 shows the procedure for sample selection. From the total of 169 companies, 57 banks and other financial service institutions were removed. Additionally, the Nigerian stock exchange delisted 25 companies during the period. Finally, 15 companies with incomplete information were dropped bringing the final sample to 72 companies or 360 firm-year observations. Data were obtained from financial statements of these listed companies accessed from Thompson Reuters DataStream, Bloomberg DataStream, and annual reports of the listed companies.

Table 1. Sample selection procedure

\begin{tabular}{lll}
\hline & No & No \\
\hline Firm listed on Nigerian stock exchange as at 31/12/2019 & 169 \\
\hline Less: & & \\
\hline Financial service companies & 57 & \\
\hline Delisted & 25 & \\
\hline Firm with incomplete data & 15 & \\
\hline Final sample & 72 \\
\hline Years & 5 \\
\hline Observation & 360 \\
\hline
\end{tabular}

\section{Dependent Variable}

Consistent with Roychowdury [55] REM was computed using abnormal cash flow, abnormal discretionary expenses, and abnormal production.

\section{Abnormal Cash flow (Ab_CFO)}

The following cross-sectional regression was executed for every firm-year for the normal cash flow.

$$
\frac{\text { CFO }_{i t}}{\text { Assets }_{I T-1}}=\alpha_{0}+a_{1}+\left(\frac{1}{\text { Assets }_{i t-1}}\right)+\beta_{1}\left(\frac{\text { Sales }_{i t}}{\text { Assets }_{i t-1}}\right)+\beta_{2}\left(\frac{\Delta \text { Sales }_{i t}}{\text { Assets }_{i t-1}}\right)+\varepsilon_{i t}
$$

$\mathrm{CFO}_{i t}$ signifies operating cash flow for firm i in year t. Asset ${ }_{\mathrm{it}-1}$ signifies lagged total assets. Sales it is existing year sales and $\Delta$ Sales it represents changes in total sales (i.e existing year sales less previous year's sales) while $\varepsilon_{i t}$ signifies the error term. The abnormal cash flow from operation (Ab_CFO) is obtained as the disparity between the actual cash flow (ACFO) and the normal cash flow (NCFO). Similar to Cohen and Zarowin (2010) the abnormal CFO residual is multiplied by (-1), since a low cash flow from operation indicates real earnings manipulation.

\section{Abnormal Discretionary Expenses (Ab_DISEXP)}

Discretionary Expenses (DISEXP) is the sum of selling, general and administration expenses, research and development and advertisement expenses. The disparity between the actual discretionary expenses and the normal discretionary expenses is the abnormal discretionary expenses (Ab_DISEXP). This discretionary spending is computed by the lagged of total assets and is regressed against the current year sales scaled by lagged total assets. Similar with Cohen and Zarowin (2010) the Ab_DISEXP is multiplied with (-1) to arrive at the final Ab_DEXP.

$$
\frac{\operatorname{DISEXP}_{i t}}{\operatorname{Assets}_{i i-1}}=a_{0}+a_{1}\left(\frac{1}{\text { Assets }_{i t-1}}\right)+\beta_{1}\left(\frac{\text { Sales }_{i t-1}}{\text { Assets }_{i t-1}}\right)+\varepsilon_{i t}
$$




\section{Abnormal Production (Ab_PROD)}

Production cost is the total of cost of goods sold (COGS) and changes in inventory $(\Delta$ Inv) for the year. The difference between actual and the normal production costs is known as abnormal production cost (Ab_PROD). The resulting regression residuals represent the real earnings management.

$$
\begin{aligned}
\frac{\text { PROD }_{i t}}{\text { Assets }_{i t-1}}=a_{1} & +a_{1}\left(\frac{1}{\text { Asset }_{i t-1}}\right)+\beta_{1}\left(\frac{\text { Sales }_{i t}}{\text { Assets }_{i t-1}}\right)+\beta_{2}\left(\frac{\Delta \text { Sales }_{i t}}{\text { Asset }_{i t-1}}\right) \\
& +\beta_{3}\left(\frac{\Delta \text { Sales }_{i t-1}}{\text { Assets }_{i t-1}}\right)+\varepsilon_{i t}
\end{aligned}
$$

\section{Real Earnings Management Matric}

Similar to Braam (2015) equations 1, 2, and 3 were aggregated to obtain a single variable $(\mathrm{REM})$ where $\mathrm{REM}=\mathrm{Ab} \_\mathrm{PROD}+\mathrm{Ab} \_\mathrm{CFO}+\mathrm{Ab} \_\mathrm{DEXP}$.

\section{Independent Variables}

Pollical connection is proxied as the proportion of politically connected directors to the total size of the board. A director is considered politically connected if he or she is (current or former) member of parliament, minister, commissioner, or head of state (Al-dhamari \& $\mathrm{Ku}$ Ismail, 2015).

\section{Control Variables}

Firm age is proxied as the number of years from the date the firm was listed (Kibiya, Ahmad, \& Amran, 2016). Also, measured firm size as the natural logarithm of the total asset (Abdul Latif, Taufil Mohd, \& Kamardin, 2016). Firm growth as the proportion changes of annual growth in total sales of the firm (Ho, Li, Tam, \& Zhang, 2015).

\section{Model Specification}

The models used in this study were based on the reviewed literature and formulated as follows.

$$
\text { REM }=\alpha_{0}+\beta_{1} \text { POLCON }_{i t}+\beta_{2} \text { FAGE }_{i t}+\beta_{3} \text { FSIZE }_{i t}+\beta_{4} \text { FGRT }_{i t}+\varepsilon
$$

Where: REM $=$ Real earnings management,$\alpha_{0}=$ Constant, POLCON $=$ Political connection, FAGE $=$ Firm age, FSIZE $=$ Firm size, FGRT $=$ Firm growth, and $\varepsilon_{i t}=$ Error term.

\section{RESULTS AND FINDINGS}

\section{Descriptive statistics}

Considering the REM, the result from Table 2 shows an average mean of 0.278 , minimum of -0.531 and a maximum value of 1.224 . The positive mean of 0.278 indicates the existence of real activities manipulation among listed firms in Nigeria. the result is comparatively higher than the mean of 0.0213 reported by Zang (2012). furthermore, the mean value of politically connected directors (POLCON) is 0.277 . This indicates that 27 per cent of board members in Nigeria are politically connected. the result provides that average FAGE is 24 years, a minimum of 4 years and maximum of 53 years. Likewise, the average score for FSIZE is 7.2 with a maximum score of 9.2. However, the average score of firm growth is 0.18 , minimum of -0.35 and a maximum of 1.82 The result indicates that the growth on annual sales average is $17 \%$ during the study period. 
Table 2. Descriptive Statistics

\begin{tabular}{llllll}
\hline Variables & Obs & Mean & Std. Dev. & Min & Max \\
\hline REM & 360 & 0.277 & 0.456 & -0.531 & 1.224 \\
\hline POLCON & 360 & 0.264 & 0.111 & 0 & 0.667 \\
\hline FAGE & 360 & 24.42 & 13.58 & 4 & 53 \\
\hline FSIZE & 360 & 7.201 & 0.763 & 5.418 & 9.17 \\
\hline FGRT & 360 & 0.179 & 0.232 & -0.358 & 1.82 \\
\hline
\end{tabular}

Note. REM $=$ Real earnings management; POLCON $=$ Political connection; FAGE $=$ Firm age; FSIZE $=$ Firm size; FGRT $=$ Firm growth $* * *$ significant at 0.01 level, $* * *$ significant at 0.05 and $*$ at 0.1 level

\section{Correlation Matrix}

Table 3 shown the outcome of the correlation matrix as none of the coefficients is greater than 0.9 as indicated by Hair et al., (2010). The highest correlation is 0.1855 between FSIZE and FGRT. Table 2 also shows that POLCON has a positive correlation with REM. While, FAGE, FSIZE, and FGRT have a significant negative correlation with REM.

Table 3. Correlation of the Study Variables

\begin{tabular}{cccccc}
\hline Variables & REM & POLCON & FAGE & FSIZE & FGRT \\
\hline REM & 1 & \multicolumn{1}{c}{} & & \\
\hline POLCON & $0.1536^{*}$ & 1 & & & \\
\hline FAGE & $-0.0294^{*}$ & -0.0308 & 1 & 1 & \\
\hline FSIZE & $-0.1573^{*}$ & -0.1382 & 0.0713 & 1 \\
\hline FGRT & -0.1173 & -0.0645 & $-0.0005^{*}$ & 0.1855 & 1
\end{tabular}

Note. REM = Real earnings management; POLCON $=$ Political connection; FAGE $=$ Firm age; FSIZE $=$ Firm size; FGRT $=$ Firm growth $* * *$ significant at 0.01 level, $* * *$ significant at 0.05 and $*$ at 0.1 level

\section{Regression Results}

This part depicts the result of linear regression carried out to check the assumption of the relationship that arise between the dependent, independent and control variable. Table 4 presents the analysis of the linear regression model.

Table 4. Result of the Estimated Regression

\begin{tabular}{lllll}
\hline REM & Coefficient & Std. Err. & $\mathbf{Z}$ & $\mathbf{P}>|\mathbf{Z}|$ \\
\hline POLCON & 0.4800976 & .1292227 & 3.72 & 0.000 \\
\hline FAGE & -0.0000135 & .0007045 & -0.02 & 0.985 \\
\hline FSIZE & -0.0719723 & .0117998 & -6.10 & 0.000 \\
\hline FGRT & -0.1109627 & .0663481 & -1.67 & 0.094 \\
\hline CONS & 0.9467626 & 0.1198547 & 7.90 & 0.000 \\
\hline Firm Fixed Effect & yes & & & \\
\hline Year Fixed Effect & yes & & & \\
\hline R Square & 0.13 & & & \\
\hline Prob $>$ F & 0.0000 & & & \\
\hline Obs & 360 & & & \\
\hline Not REM Rean & & & & \\
\hline
\end{tabular}

Note. REM = Real earnings management; POLCON= Political connection; FAGE = Firm age; FSIZE $=$ Firm size; FGRT $=$ Firm growth

Table 4 show the regression outcome on the association between dependent and independent variable. The result show that POLCON has a significant positive (Coeff 0.480, $\mathrm{P}=0.000$ ) with REM. The finding shows that firms board with political connection are possible to have earnings manipulation which deteriorate the earnings quality. This is consistent with the grabbing hand that firms use their political connection to divert the resources of the firm. Also, 
the result is similar with the findings of Al-dhamari and $\mathrm{Ku}$ Ismail (2015) that politically connected firms are associated with lower earnings quality.

The result also show that FAGE has insignificant association (Coeff $-0.000, \mathrm{P}=0.985$ ) with REM. This suggest that firms age do not play a role in management manipulating the earning. FSIZE is negatively significant (Coeff-0.0719, $\mathrm{P}=0.000)$ related to REM. Showing that larger firms based on their total asset do not engage in earnings manipulation thereby have a higher earnings quality. FGRT was negatively but insignificantly (Coeff-0.1109, P=0.094) related with REM.

\section{CONCLUSION}

This paper examines the effect of political connection on real earnings management in the context of Nigeria. Thus, the study evidenced that the presence of politically connected director's influence managers to engage in earnings manipulation which affect the quality of the financial statement. Thus, this study recommends that increased attention should be given to internal control mechanisms to help curtail corporate earnings manipulations, reduce the effect of political connection, and enhance the financial reporting quality, particularly in Nigeria and other comparable countries.

\section{REFERENCES}

Abdul Latif, R., Taufil Mohd, K.N. and Kamardin, H. (2016), "CEO characteristics and frequency of share repurchases", Information (Japan), Vol. 19 No. 18A, pp. 31553160 .

Abdul Wahab, N. S., \& Holland, K. (2012). Tax planning, corporate governance and equity value. British Accounting Review, 44(2), 111-124.

Abubakar, A. H., Lawal, A. M., \& Mohamed, M. I. (2020). Ownership Structure and Real Earnings Management: Evidence from Nigeria. The Journal of Management Theory and Practice (JMTP), 1(3), 43-50.

Al-Dhamari, R. and Ku Ismail, K.N.I. (2015), "Cash holdings, political connections, and earnings quality: some evidence from Malaysia", International Journal of Managerial Finance, Vol. 11 No. 2, pp. 215-231, available at: https://doi.org/10.1108/IJMF-022014-0016

Bala, H., Amran, N. A., \& Shaari, H. (2019). Audit committee attributes and cosmetic accounting in Nigeria. Managerial Auditing Journal, 35(2), 177-206.

Braam, G., Nandy, M., Weitzel, U., \& Lodh, S. (2015). Accrual-based and real earnings management and political connections. The International Journal of Accounting, 50(2), 111-141.

Cao, J., Lemmon, M. L., Pan, X., \& Tian, G. G. (2009, November). Political promotion, CEO compensation and their effect on firm performance. In AFA 2011 Denver Meetings Paper.

Chaney, P. K., Faccio, M., \& Parsley, D. (2011). The quality of accounting information in politically connected firms. Journal of Accounting and Economics, 51(1-2), 58-76.

Cohen, D. A., \& Zarowin, P. (2010). Accrual-based and real earnings management activities around seasoned equity offerings. Journal of Accounting and Economics, 50(1), 2-19.

Ghonji Feshki, A., Khanmohammadi, M. H., \& Yazdani, S. (2020). Political Connection and Earnings Management Methods: Evidence from Tehran Stock Exchange. International Journal of Finance \& Managerial Accounting, 5(17), 1-17.

Ghonji Feshki, A., Khanmohammadi, M. H., \& Yazdani, S. (2020). Political Connection and Earnings Management Methods: Evidence from Tehran Stock Exchange. International Journal of Finance \& Managerial Accounting, 5(17), 1-17. 
air, J. F., Black, W. C., Babin, B. J., \& Anderson, R. E. (2010). Multivariate data analysis. Prentice-Hall, Inc.

Healy, P. M., \& Wahlen, J. M. (1999). A review of the earnings management literature and its implications for standard setting. Accounting Horizons, 13(4), 365-383.

Ho, S. S., Li, A. Y., Tam, K., \& Zhang, F. (2015). CEO gender, ethical leadership, and accounting conservatism. Journal of Business Ethics, 127(2), 351-370.

Jaffar, R., \& Abdul- Shukor, Z. (2016). The role of monitoring mechanisms towards the company's Performance: Evidence from Politically connected Companies in Malaysia. Journal of Accounting in Emerging Economics, 6(4), 408-428.

Junaidi, R. R., \& Siregar, S. V. (2020). The effect of political connection and earnings management on management compensation. International Journal of Business and Globalisation, 26(1-2), 92-118.

Kibiya, M.U., Ahmad, A.C. and Amran, N.A. (2016), "Audit committee characteristics and financial reporting quality Nigerian", The European Proceedings of Social and Behavioural Sciences, III, May, 1292-1304.

Lo, K., Ramos, F., \& Rogo, R. (2017). Earnings management and annual report readability. Journal of Accounting and Economics, 63(1), 1-25.

Ma, L., Ma, S., \& Tian, G. (2013). Political connections, founder-managers and their impact on tunneling in China's listed firms. Pacific Basin Finance Journal, 24, 312-339.

Ngan, S. C. (2013). The impact of politically-connected executives in fraudulent financial reporting: Evidence based on the $\mathrm{H}$ shares1. African Journal of Business Management, 7(18), 1875-1884.

Nwanyanwu, L. A. (2017). Audit quality practices and financial reporting in Nigeria. International Journal of Academic Research in Accounting, Finance and Management Sciences, 7(2), 145-155.

Osazuwaa, N. P., Che-Ahmad, A., \& Adam, N. (2016). Political connection, board characteristics and firm performance in Nigeria. The European Proceedings of Social and Behavioral Sciences, 769-774.

Rahman, W. N. W. A., \& Mansor, N. (2018). Real earnings management in family group affiliation: A research proposal. International Journal of Accounting, 3(11), 82-96.

Roychowdhury, S. (2006). Earnings management through real activities manipulation. Journal of accounting and economics, 42(3), 335-370.

Song, Y., Wang, L., \& Yan, Z. (2011). Impacts of political connections on earnings quality. Journal of. Advance in Education and Management, 4, 85-92.

Wang, L. (2015). Protection or expropriation: politically connected independent directors in China. Journal of Banking and Finance, 55, 92-106.

Wong, W. Y., \& Hooy, C. W. (2018). Do types of political connection affect firm performance differently?. Pacific-Basin Finance Journal, 51, 297-317.

Zang, A. Y. (2012). Evidence on the trade-off between real activities manipulation and accrual-based earnings management. The accounting review, 87(2), 675-703.

Zhang, J (2014). Political connection and corporate fraud: Theory and evidence from China.observer-ews. https://saisobserver.org/2014/03/03/politicalconnection-and corporate-fraud-theory-and-evidence. 